\title{
Investigation and Testing of Methods to Measure Changes in Microbial Populations Due to the Use of Oxygenates in Fuels Released to the Subsurface
}

\author{
A. Happel, T. Legler, S. Kane
}

Lawrence

February 7, 2002

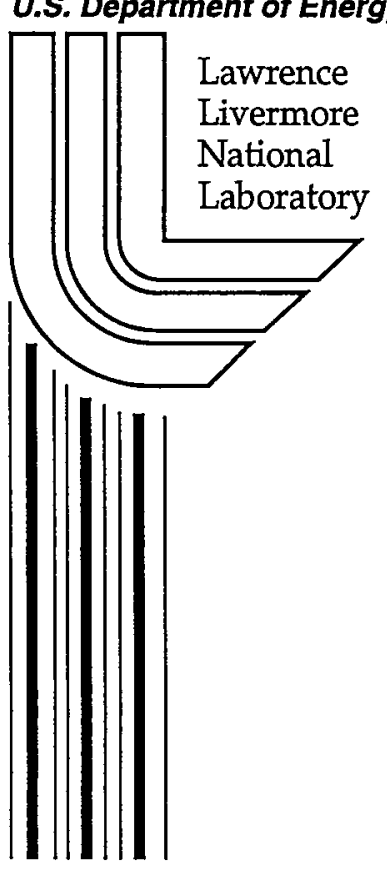




\section{DISCLAIMER}

This document was prepared as an account of work sponsored by an agency of the United States Government. Neither the United States Government nor the University of California nor any of their employees, makes any warranty, express or implied, or assumes any legal liability or responsibility for the accuracy, completeness, or usefulness of any information, apparatus, product, or process disclosed, or represents that its use would not infringe privately owned rights. Reference herein to any specific commercial product, process, or service by trade name, trademark, manufacturer, or otherwise, does not necessarily constitute or imply its endorsement, recommendation, or favoring by the United States Government or the University of California. The views and opinions of authors expressed herein do not necessarily state or reflect those of the United States Government or the University of California, and shall not be used for advertising or product endorsement purposes.

This work was performed under the auspices of the U. S. Department of Energy by the University of California, Lawrence Livermore National Laboratory under Contract No. W-7405-Eng-48.

This report has been reproduced directly from the best available copy.

Available electronically at http://www.doe.gov/bridge

Available for a processing fee to U.S. Department of Energy and its contractors in paper from

U.S. Department of Energy

Office of Scientific and Technical Information

P.O. Box 62

Oak Ridge, TN 37831-0062

Telephone: (865) 576-8401

Facsimile: (865) 576-5728

E-mail: reports@adonis.osti.gov

Available for the sale to the public from

U.S. Department of Commerce

National Technical Information Service

5285 Port Royal Road

Springfield, VA 22161

Telephone: (800) 553-6847

Facsimile: (703) 605-6900

E-mail: orders@ntis.fedworld.gov

Online ordering: http://www.ntis.gov/ordering.htm

OR

Lawrence Livermore National Laboratory

Technical Information Department's Digital Library

http://www.llnl.gov/tid/Library.html 


\section{Investigation and Testing of Methods to Measure Changes in Microbial Populations Due to the Use of Oxygenates in Fuels Released to the Subsurface \\ Mid-year LDRD 01-ERD-084 Final Report}

Anne Happel, Tina Legler, and Staci Kane

UCRL

\section{Background and Rationale}

Current bioremediation and risk-management practices are being adapted to the increasing possibility of encountering oxygenates (primarily methyl tert-butyl ether, MTBE, and ethanol) as co-contaminants at the approximately 400,000 leaking underground fuel tank (LUFT) sites nationwide. However, little is known about the effect of oxygenates on microbial populations and the resulting shifts in the microbial ecology and catabolic diversity that may result from the inclusion of oxygenates in reformulated gasoline. Among the possible effects are enrichment of oxygenatedegrading bacteria in relation to BTEX (benzene, toluene, ethylbenzene and xylenes)degrading bacteria, the fortuitous enrichment of bacteria that can degrade both oxygenates and BTEX compounds, no effect on BTEX-degrading populations, or decreases in populations of certain bacteria as a result of toxicity (for example, a possible synergistic toxic effect from the combined presence of ethanol and BTEX).

Indigenous microbial communities often degrade BTEX using electron acceptors preferentially in order of decreasing reduction potential (Chapelle, 1993). Sequential depletion of electron acceptors often leads to successive transitions from aerobic to 
denitrifying, iron-reducing, sulfate-reducing, and methanogenic conditions. Oxygenates may contribute to the depletion of electron-acceptor pools during their microbial degradation, and this depletion is likely to affect temporal and spatial transitions in electron-accepting conditions during natural attenuation of petroleum-product releases. The changes in the microbial community associated with geochemical transitions are important to study because they affect BTEX degradation rates and therefore, the migration of BTEX contaminated groundwater plumes that could impact drinking water supplies. Aerobic degradation rates for individual BTEX compounds are significantly more rapid than those observed under anaerobic conditions (Hutchins, 1991). Furthermore, the half-life of the oxygenate, ethanol, is shorter under aerobic conditions relative to anaerobic conditions (Alvarez et al., 1999). In addition, aerobic in situ biodegradation of MTBE has been reported (Wilson et al., 2002; Salanitro et al., 2000), whereas, its degradation under anaerobic conditions has not been widely documented. Therefore, it is important to understand how electron acceptor availability is affected by oxygenates and, how shifts in electron acceptor pools affect the presence and activity of hydrocarbon- and oxygenate-degrading microbial populations.

Methods for quantifying subsurface microbial populations have shifted from culture-based approaches, which rely on growth of indigenous microorganisms under laboratory conditions, to nucleic acid-based approaches. The culture-based methods typically count less than $1 \%$ of the total population of microorganisms in an 
environmental sample, whereas the DNA- or RNA-based approaches are not limited to groups of microorganisms that can be cultured. The nucleic acid-based or molecularbased methods use a unique sequence as a tag or identifier for a given population. Traditional molecular methods have included DNA:DNA hybridization, which uses a labeled DNA fragment as a "probe" to detect a specific group of microorganism. "Stateof-the-art" molecular technologies such as real-time quantitative Polymerase Chain Reaction (PCR) (Heid et al., 1996) have much lower detection limits than traditional methods; for example, detection limits less than 10 microorganisms in a sample have been reported (Hristova et al., 2001; Gruntzig et al., 2001).

Despite the advantages of molecular-based methods, one limitation to their widespread usage is the lack of available DNA sequence information. Furthermore, for detection and quantification of hydrocarbon-degrading microorganisms, the use of sequences based on presence of a functional or catabolic gene is preferred to the use of sequences that are specific to a phylogenetic group of microorganisms (i.e., ribosomal DNA), since a similar phylogenetic group often has diverse metabolic potential. While the genes involved in MTBE degradation are unknown, many catabolic genes have been identified for the degradation of BTEX compounds. Several aerobic degradation pathways have been characterized both biochemically and genetically (See Table 1 for references). For anaerobic BTEX degradation pathways, several biochemical studies have been conducted for hydrocarbon-degraders using different electron acceptors (e.g., 
Biegert et al., 1996; Beller and Spormann, 1997; Beller and Edwards, 2000), however, genetic analysis has been limited to the denitrifying bacteria (Leuthner et al. 1998; Coschigano et al. 1998; Achong et al. 2001).

\section{Research Focus and Objectives}

The focus of this mid-year LDRD project was to investigate the limitations and potential for genetic probes to be used to quantify shifts in bacterial communities due to the presence of oxygenates in gasoline released to the subsurface. Since more information was available for the genetic pathways for aerobic BTEX degradation, a major emphasis was placed on gene probes for aerobic microorganisms. The approaches used in this study could also be applied to anaerobic BTEX degradation pathways and to MTBE degradation pathways as the sequence information becomes available in the database. The project objectives were to:

1. Design and produce genetic probes that are specific to aerobic BTEX degradation pathways.

2. Perform laboratory tests to determine how specific or conversely, how "robust" are these genetic probes. 
The overall goal was to develop laboratory tools that would allow one to quantify the effects of changes in the microbial community due to the use of oxygenates in reformulated gasoline. Presumably, shifts in populations of hydrocarbon-degraders using a given electron-acceptor would be correlated with shifts in concentrations of that electron-acceptor in the subsurface.

\section{Research Approach}

A variety of microbial strains containing genes coding for different biochemical pathways of aerobic BTEX degradation were selected for development of gene probes. The genes that correspond to unique BTEX degradation pathways that were investigated are shown in Table 1.

Distinctive regions $(<300 \mathrm{bp})$ that appeared to be specific to the given pathway were selected from these genes after comparison with related genes in the GenBank database. Primers for PCR amplification were designed using MacVector software (version 6.1, Accelrys, San Diego, CA) for these distinct regions. The primer sequences were screened for potential cross-reactivity with other related but non-target DNA sequences (i.e., genes for a different pathway) using the GenBank nucleotide BLAST program (National Center for Biotechnology Information, Bethesda, MD). Primers that met the criteria for specificity were used to develop gene probes for conventional 
DNA:DNA hybridization analysis. DNA sequences were also evaluated for their "robustness" or their ability to target different genetic pathways which code for enzymes

Table 1. Genes coding for enzymes involved in aerobic BTEX degradation.

\begin{tabular}{|c|c|c|c|c|}
\hline Gene & Enzyme coded for & Host bacterium & $\begin{array}{c}\text { GenBank } \\
\text { Accession } \\
\text { Number }^{2} \\
\end{array}$ & Reference \\
\hline todC1 & $\begin{array}{l}\text { toluene } \\
\text { dioxygenase, } \alpha \text { - } \\
\text { subunit of } \\
\text { oxygenase }\end{array}$ & $\begin{array}{l}\text { Pseudomonas } \\
\text { putida } \mathrm{F} 1\end{array}$ & J04996 & $\begin{array}{l}\text { Zylstra and } \\
\text { Gibson, } 1989\end{array}$ \\
\hline tmoE & $\begin{array}{l}\text { toluene-4- } \\
\text { monooxygenase, } \\
\text { putative oxygenase }\end{array}$ & P. mendocino $\mathrm{KR} 1$ & M65106 & $\begin{array}{l}\text { Yen et al., } \\
1991\end{array}$ \\
\hline tbuA2 & $\begin{array}{l}\text { toluene-3- } \\
\text { monooxygenase, } \\
\text { meta-hydroxylase, } \\
\text { putative subunit }\end{array}$ & $\begin{array}{l}\text { Ralstonia pickettii } \\
\text { PKO1 }\end{array}$ & U04052 & $\begin{array}{l}\text { Byme et al., } \\
1995\end{array}$ \\
\hline touA & $\begin{array}{l}\text { toluene/o-xylene } \\
\text { monooxygenase, } \\
\text { oxygenase subunit }\end{array}$ & P. stutzeri OX1 & AJ005663 & $\begin{array}{l}\text { Bertoni et al., } \\
1998\end{array}$ \\
\hline tbhE & $\begin{array}{l}\text { toluene-3- } \\
\text { monooxygenase } \\
\text { oxygenase subunit } 2\end{array}$ & $\begin{array}{l}\text { Burkholderia } \\
\text { cepacia AA1 }\end{array}$ & AF001356 & $\begin{array}{l}\text { Ma and } \\
\text { Herson, } 1997\end{array}$ \\
\hline$t b m B$ & $\begin{array}{l}\text { toluene/benzene-2- } \\
\text { monooxygenase, } \\
\text { oxygenase subunit }\end{array}$ & $\begin{array}{l}\text { Pseudomonas sp. } \\
\text { JS150 }\end{array}$ & L40033 & $\begin{array}{l}\text { Johnson and } \\
\text { Olsen, } 1995\end{array}$ \\
\hline$x y l M$ & $\begin{array}{l}\text { xylene } \\
\text { monooxygenase, } \\
\text { hydroxylase } \\
\text { component }\end{array}$ & $P$. putida TOL mt-2 & M37480 & $\begin{array}{l}\text { Suzuki et al., } \\
1991\end{array}$ \\
\hline
\end{tabular}

a National Center for Biotechnology Information, Bethesda, MD. 
with related functions (i.e., they catalyze the addition of oxygen to an aromatic ring). A general probe for aerobic BTEX degradation potential would perhaps be more efficient in quantifying the whole community of microorganisms capable of aerobic BTEX degradation.

\section{Research Findings}

Reference strains were obtained from individual research laboratories for all seven of the genes listed above. The strains were grown in liquid media with toluene as a selective substrate for growth, except for $P$. putida TOL mt-2, which did not grow on defined media with toluene as sole carbon source. PCR conditions were optimized for the given PCR experiment using a range of buffers and annealing temperatures. After PCR experiments were conducted, the resulting PCR products were analyzed by gel electrophoresis to determine if the correct size fragment was amplified. PCR products were subsequently cloned and sequenced to ensure that the correct region was amplified.

PCR products of the correct size and containing the correct sequence were obtained from all but one of the reference strains; no correct PCR product was obtained for generating the $x y l M$ probe. The reference strain for the $x y l$ pathway ( $P$. putida TOL mt-2) did not grow on toluene media so there was likely a problem with the template DNA used for PCR amplification of the $x y l M$ probe. 
It was noted that some reference strains contained multiple pathways for BTEX degradation, so that cross-reactivity of genomic DNA from different reference strains would not be an accurate measure of the cross-reactivity of specific gene probes. For example, Pseudomonas sp. JS150 containing the $t b m$ pathway (Table 1.) also contained sequences related to the toluene dioxygenase (tod) pathway. Therefore, tests for crossreactivity of probes were designed such that individual probes would be used as targets in DNA hybridization analysis or as templates in real-time quantitative PCR analysis.

Environmental samples were spiked with Pseudomonas putida strain F1 bacteria containing todCl $\left(10^{9}\right.$ per $\mathrm{g}$ soil) in order to determine extraction efficiency and detection limits for hybridization and PCR-based methods. A modification of the method described by Zhou et al. (1996) was used and extraction efficiencies greater than $70 \%$ were typically obtained (relative to the number of spiked cells). The results using this target organism demonstrated that the laboratory tools developed in this study could be used to track specific BTEX-degrading populations to very low detection limits $(<100$ organisms per g sediment) using PCR-based approaches, whereas, detection limits were on the order of $10^{5}$ for hybridization-based detection. PCR quantification methods are well suited to detection of specific target microorganisms (Gruntzig et al., 2001).

Based on study findings, it is expected that more general probes for detecting related but not identical gene sequences could also be developed, although the major focus of this study was on specific gene sequences. Hybridization-based detection 
methods would likely be more robust in this regard than PCR-based methods which involve annealing of short (20-30 bp) DNA regions. Hybridization analysis with larger DNA fragments (hundreds of base pairs) used as probes would allow for more sequence divergence in the target DNA since specific priming for amplification is not required. In order to reduce the potential for detection and quantification of false positives, high stringency conditions should be used in DNA:DNA hybridization analysis. PCR quantification methods are better suited to detection of specific target microorganisms (Gruntzig et al., 2001), and thus it may be more difficult to develop more "robust" primers for PCR applications.

This study provided some preliminary information for the development of methods to determine the effect of oxygenates on the microbial community responsible for aerobic BTEX degradation. Additional work is required to optimize the primers and probes developed as part of this study and to test their application in field samples. As sequence information becomes available in the database for other relevant catabolic pathways, such as for MTBE degradation, the approaches used in this study can be used to develop primers and probes for these microbial populations in environmental samples as well. 
References

Achong, G. R., A. M. Rodriguez, and A. M. Spormann. 2001. Benzylsuccinate synthase of Azoarcus sp. strain T: cloning, sequencing, transcriptional organization, and its role in anaerobic toluene and $m$-xylene mineralization. J. Bacteriol. 183: 6763-6770.

Alvarez, P. J. J., and C. H. Hunt. 1999. "The effect of ethanol on BTEX biodegradation and natural attenuation", Chapter 3, Volume 4, "Potential Ground and Surface Water Impacts" In: D. Rice and G. Cannon (eds.) Health and Environmental Assessment of the Use of Ethanol as a Fuel Oxygenate. UCRL-AR-135949.

Beller, H. R., and E. A. Edwards. 2000. Anaerobic toluene activation by benzylsuccinate synthase in a highly enriched methanogenic culture. Appl. Environ. Microbiol. 66: 55035505.

Beller, H. R., and A. M. Spormann. 1997. Benzylsuccinate formation as a means of anaerobic toluene activation by sulfate-reducing strain PRTOL1. Appl. Environ. Microbiol. 63: 3729-3731.

Bertoni, G., M. Martino, E. Galli, and P. Barbieri. 1998. Analysis of the gene cluster encoding toluene/o-xylene monooxygenase from Pseudomonas stutzeri OX1. Appl. Environ. Microbiol. 64: 3626-3632. 
Biegert, T., G. Fuchs, and J. Heider. 1996. Evidence that anaerobic oxidation of toluene in the denitrifying bacterium Thauera aromatica is initiated by formation of benzylsuccinate from toluene and fumarate. Eur. J. Biochem. 238: 661-668.

Byrne, A. M., J. J. Kukor, and R. H. Olsen. 1995. Sequence analysis of the gene cluster encoding toluene-3-monooxygenase from Pseudomonas pickettii PKO1. Gene 154: 6570.

Chapelle, F. H. 1993. Ground-water Microbiology and Geochemistry. John Wiley \& Sons, Inc. New York, NY.

Coschigano, P. W., T. S. Wehrman, and L. Y. Young. 1998. Identification and analysis of genes involved in anaerobic toluene metabolism by strain $\mathrm{T} 1$ : putative role of a glycine free radical. Appl. Environ. Microbiol. 64: 1650-1656.

Grüntzig, V., S. C. Nold, J. Zhou, and J. M. Tiedje. 2001 Pseudomonas stutzeri nitrite reductase gene abundance in environmental samples measured by real-time PCR. Appl. Environ. Microbiol. 67: 760-768.

Heid, C. A., J. Stevens, K. J. Livak, and P. M. Williams. 1996. Real-time quantitative PCR. Genome Res. 6: 986-994.

Hristova, K. R., C. M. Lutenegger, and K. M. Scow. 2001. Detection and quantification of methyl tert-butyl ether-degrading strain PM1 by real-time TaqMan PCR. Appl. Envir. Microbiol. 67: 5154-5160. 
Hutchins, S. R. 1991. Biodegradation of monoaromatic hydrocarbons by aquifer microorganisms using oxygen, nitrate, or nitrous oxide as the terminal electron acceptor. Appl. Environ. Microbiol. 57: 2403-2407.

Johnson, G. R., and R. H. Olsen. 1995. Nucleotide sequence analysis of genes encoding a toluene/benzene-2-monooxygenase from Pseudomonas sp. strain JS150. Appl. Environ. Microbiol. 61: 3336-3346.

Leuthner, B., C. Leutwein, H. Schulz, P. Hörth, W. Haehnel, E. Schiltz, H. Schägger, and J. Heider. 1998. Biochemical and genetic characterization of benzylsuccinate synthase from Thauera aromatica: a new glycyl radical enzyme catalysing the first step in anaerobic toluene metabolism. Mol. Microbiol. 28: 615-628.

Ma, Y., and D. S. Herson. 2000. The catechol 2,3-dioxygenase gene and toluene monooxygenase genes from Burkholderia $s p$. AA1, an isolate capable of degrading aliphatic hydrocarbons and toluene. J. Ind. Microbiol. Biotechnol. 25: 127-131.

Salanitro, J. P., P. C. Johnson, G. E. Spinnler, P. M. Maner, H. L. Wisniewski, and C. Bruce. 2000. Field-scale demonstration of enhanced MTBE bioremediation through aquifer bioaugmentation and oxygenation. Environ. Sci. Technol. 34: 4152-4162.

Suzuki, M., T. Hayakawa, J. P. Shaw, M. Rekik, and S. Harayama. 1991. Primary structure of xylene monooxygenase: similarities to and differences from the alkane hydroxylation system. J. Bacteriol. 173:1690-1695. 
Wilson, R. D., D. M. Mackay, and K. M. Scow. 2002. In situ MTBE biodegradation supported by diffusive oxygen release. Environ. Sci. Technol. 36: 190-199.

Yen, K.-M., M. R. Karl, L. M. Blatt, M. J. Simon, R. B. Winter, P. R. Fausset, H. S. Lu, A. A. Harcourt, and K. Chen. 1991. Cloning and characterization of a Pseudomonas medocina KR1 gene cluster encoding toluene-4-monooxygenase. J. Bacteriol. 173: $5315-5327$.

Zhou, J., M. A. Bruns, and J. M. Tiedje. 1996. DNA recovery from soils of diverse composition. Appl. Envir. Microbiol. 62: 316-322.

Zylstra, G. J., and D. T. Gibson. 1989. Toluene degradation by Pseudomonas putida F1: Nucleotide sequence of the todC1C2BADE genes and their expression in E. coli. J. Biol. Chem. 264: 14940-14946. 